\title{
PETIT APARTHEID AND THE "TB" SYNDROME: POLICE RACIAL PROFILING OF CHICANA/O YOUTHS IN SAN JOSE, CALIFORNIA
}

\author{
Robert Koehler \\ Harvard Divinity School
}

I like to go out on Friday nights and Saturday nights and join up with my homies and walk around the hot spots and get some food. I like to check out the girls and see if I can get something going with them. But every weekend the cops stop me. What the fuck for? I go to school everyday and get treated like a criminal and then, when I want to step out of my house...I get treated like a criminal again! I have never been arrested for nothing! But I always get stopped for walkin' down the street. For walkin' down the street! Am I in a gang (the police ask)? Who's in a gang? Who's carrying a gun, a disrepectful attitude, and stopping people for nothing? The police gang. You don't see me with a gun or knife or harassing anyone! I'm just tryin' to walk down the fucking street an anonymous sixteen year-old Chicano (Author, 2004)

\section{INTRODUCTION}

This study examined police racial profiling (PRP) of Chicana/o youths in San Jose, Califomia, when they were outside of, or walking to/from, Taco Bell restaurants (TBs). Dickey found the San Jose Police Department (SJPD) labcled TBs "the fast-food choice of gangs" and "a tremendous problem for law enforcement' because some gangs have established individual Taco Bells as 'their turf" (Sept. 19, 1993: 1B). Chicano/a activists claimed police harassed "youths at Taco Bells without cause and dismissed the idea that the fast-food restaurants have become the choice of gang members" (Dickey: 1B). Years after designation of TBs as gang turf, Chicana/o youths claim harassment by police at/near TBs continues (Author 2003).

The alleged harassment purportedly increases on Friday and Saturday nights. According to a twenty-six year-old Chicano, "Even when I was a kid the cops would stop us at Taco Bell and tell us we were loitering in the parking lot, but we were eating, and then they asked us all type of stupid questions and it still has not stopped. That's why I don't go there at night anymore" (Author, 2004). He refused to patronize TBs, as he believed police would question him, especially on weekend nights when police presence was greater at/near TBs. A sixteen year-old and a twenty-two year-old, stated that police questioning and detainment of Chicana/o youths at/near TBs is known as the Taco Bell, or TB, syndrome because "When you're Chicano and you get near a Taco Bell you automatically become a criminal and get questioned" (Author, 2002). This study found that Chicana/o and Asian American, predominately Vietnamese American, youths had higher police questioning and stop-and-frisk episodes (PQSFE) than White youths at/near TBs. Police racially 


\section{Ethnic Studies Review Volume 30: 1\&2}

profiling, stopping, questioning, and frisking minority youths are petit apartheid practices based in pre-civil rights de jure racism.

De jure racism transformed into de facto racism. Criminal justice policies and practices preserved via de jure oppression changed into discrimination under the guise of discretion. Prior grand apartheid, oppressive laws, transformed into a petit apartheid systern of accepted mores and way of life (Milovanovic \& Russell 2001: xii). Institutional racism, derived from America's historical overt racism, codifies and legitimates itself by de jure means (Georges-Abeyie 1990:28). Petit apartheid is the daily insults, harsh conduct, and racially motivated police stops, questionings, and searches of minorities; the mistreatment of minority suspect and arrestees; the inferior value, cleamess, and impartiality of judges' directions to jurors when minorities are on trial; acceptance of inferior standards of evidence resulting in convictions of minorities, and; other retaliatory discretionary undertakings by the criminal justice system, correctional guards and administrators, and jurors (Milovanovic \& Russell: viii). Petit apartheid explains San Jose police officers' discretionary tactics that are accepted law enforcement.

The backstage aids in explaining why PRP, "the inappropriate consideration by law enforcement of race or ethnicity in deciding with whom and how to intervene in an enforcement capacity," of minority youths is sanctioned (Fridell 2004: 1). The backstage is "relative to a given performance, where the impression fostered by the performance is knowingly contradicted as a matter of course" (Goffman 1973: 112). The backstage is where racially-biased decisions are fashioned (i.e., police designating minority youths for PQSFE). The back region is not a formal stage (i.e., anest), so there is little, if any, official record of decision-making or if race was a determinant. Consequently, racially motivated decisions formulated in the backstage are presented to the public as racially neutral (Milovanovic \& Russell: 6). Backstage events, such as decisions to enact racial profiling through baseless police stops and questioning of minority youths, occur in public but are acceptable and subtle practices that harm those profiled.

There are two intertwined harms from PRP: harms of reduction and harms of repression. Harms of reduction occur when a slighted individual suffers a loss of some condition relative to their existing status whereas harms of repression occur when an individual suffers a constraint precluding them from realizing a preferred status (Milovanovic \& Russell:xvi). An example of a harm of repression is when women and men of color are denied advancement in their profession due to sexism and/or racism. An example of a harm of reduction is police stopping minority motorists solely due to their race, the police reduce the motorist from equal citizenship status with whites by racial profiling and tangeting for motorist stops. These harms move an individual away from a position they presently occupy, or deny them a desired position (Milovanovic \& Russell: xvi). They are harmful because they belittle, demean, ridicule or subordinate, and limit access to equal opportunity and justice before the law (e.g., DWBB [driving while Black or Brown], SWBB [standing while Black or Brown]). Police petit apartheid practices combine with backstage decisions to limit access of minorities and poor to public space. 


\section{THE ORIGINS OF POLICE RACIAL PROFILING AND RACE, SPACE, AND PLACE}

Preservation of spatial sovereignty is the primary state function and ranges from national security to domestic spaces (Bass 2001: 43). Racial and spatial policing have been legitimated in govemmental policies such as Manifest Destiny, the Indian reservation system, varied Asian Exclusion Acts, Japanese American Intemment duning World War II, and restrictions on legal and illegal immigration (Fagan \& Davies 2000: 459). The term "racial profiling" came into use in the 1990s, but concems about racially based police decisions date back centuries (Fridell: vi).

Slave codes were fundarnental to American criminal law from 1619 to 1865 (Russell 1998: 14). In 1693 Philadelphia, free and slave Blacks faced detention if found on city streets without a pass from their master (Maclin 1998: 435). Slave patrols enforced the codes and prevented Blacks from transgressing the physical, social, and psychological spaces that maintained White hegemony. Slave patrols were early spatial police. With the end of slavery, Southem White Americans shaped the Black Codes prolonging domination of Blacks. As the potency of the Black Codes diminished under legal attacks, Southemers fashioned Jim Crow laws. These laws reaffirmed and reminded Blacks of their lesser place (Bass: 45). Jim Crow laws, like Slave and Black Codes, set race-based guidelines for the social spaces Blacks could occupy. Such space laws set physical space boundaries and psychological space and place boundaries. They prevented social intermixing of Whites and Blacks while maintaining the superior, clean, status of Whites and the inferior, polluted, status of Blacks. Significant in these codes and laws was preservation of race-based hierarchies. Similar laws and hierarchies applied to Chicana/os.

After the Mexican American War, Chicana/os in the Southwest had similar experiences to Blacks. Despite the Treaty of Guadalupe Hidalgo's guarantees, an array of legal and extralegal measures removed Chicana/os from their land. The state created a double standard of justice to preserve White interest and subordinate Chicana/os (Mirandé 1987: 2 and 23). The Texas Rangers became spatial police of the late nineteenth-century Southwest. They limited Chicana/os access to White physical, social, and psychological space. The Texas Rangers combined vigilantism with legally sanctioned state violence (Mirandé: 67$)$. Funthermore, Mirandé contended that rank-and-file law enforcement officers perpetrated beatings and killings of Chicana/os along the border in the 1970s (23). After generations of conflict Chicana/os, especially male youths, distrust the police (Mirandé 1981; Morales 1972: 2). Mirandé termed police attitudes and practices toward Chicana/os "gringo justice"(1987). 


\section{RACE, SPACE, AND PLACE IN TWENTY-FIRST CENTURY AMERICA}

The segregation of Blacks into ghettos and Chicana/os into bamios, and restrictions on their movement in urban spaces limited their civil liberties (Bass: 45). Economic restructuring increased urban poverty and constructed new spaces endangered by poverty. Poverty increased regulation and exclusion and gave rationale for the rise of zero tolerance/quality of life policing (Parenti 1999: 70). Exclusion to/in social space is routine to urban life (Sibley 1995: xiv).

Cities segregated into areas for clean (White, middle and upper class) and polluted (minority and/or lower class). These stereotypes are fundamental to the constnuction of social and spatial exclusion (Sibley: 18). The clean live in socially purified neighborhoods (Sibley: 38 and 77). To the disenfranchised such spaces comprise landscapes of domination. They are alienating and action by the disenfranchised represents deviancy and immorality/pollution to the privileged (Sibley: 76). Police enact public and backstage polices that maintain the social purity of affluent neighborhoods. They ensure polluted do not cross into clean space. Policing segregated areas differs from policing predominantly white neighborhoods as "residential segregation created cognitive boundaries that defined those places that were relegated to racial minorities and those that were not. African Americans, and other minorities, who venture outside their neighborhoods were often subject to police harassment for having the temerity to circulate 'out of their place"' (Bass: 45-6). Clean spaces emphasize order and social homogeneity preserved by unonistakable delineation of boundaries between clean and polluted and emphasizing conformity and identification of deviance. Spatial boundaries are moral boundaries (Sibley: 39 ).

New tactics in urban control seek to regain public spaces while removing unwanted populations and regulating "the meaning of such people and spaces as well" (Cole 2001: 14). Cultural spaces can have meanings that "vary based on one's knowledge, belief, and experience but provide the basis for one's visualization of that particular place" (Frazier, Maryai \& Tettey-Fio 2003: 9). Because public spaces have contested cultural meanings and identities, they are essential zones of conflict and control (Frazier et al.: 14). Urban sociospatial processes are essential in understanding the racializod geographies of cities (MoCann 1999: 168). Capitalist societies require and generate abstract space distinguished by social fragmentation, homogenization, and hierarchization (MoCann: 170).

Abstract space is represented by elite as "homogeneous, instnmental, and ahistorical" in order to realize state supremacy and the free flow of capital that allows downtown business districts to be the almost exclusive domain of White, middle-class males (MoCann: 164). Meanings conveyed by abstract space are generally prohibitions. Abstract symbols and meanings defend elite spaces, wealthy neighborhoods, and gated communities (Ferrell, 2001, pp. 5 and 11). Policed public spaces keep encoumters between "clean" and "polluted" to a minimum.

There is an imperfect assignment of abstract space (commodifiedbureaucratized) above concrete space (everyday life/experience) (MoCann: 168). For abstract space to become dominant there must be an attempt to designate the appropriate meanings and activities within that space (168). This involves an agreernent to pacifism and formation of spatial economy in which people engage in 
relationships with capitalist enterprises (i.e., theatres, restaurants, and cafes). The rise of abstract space necessitates disregarding city's racialized geography and history and creating an impression of homogeneity and unity that must be "achieved and maintained through a continued state-sponsored process of fragmentation and marginalization that elides difference and thus attempts to prevent conflict' (168-70). Prohibited individuals intrusion into forbidden space results in prosecution for unlawful entry. State prosecution can be via the police and policies formulated in the backstage such as intimidation, beatings, PQSFE, and driving the polluted outside city limits and leaving them ("starlight tours") (Razack 2002: 8).

\section{POLICE STOP-AND-FRISKS: TERRY V.OHIO}

Before Terry v. Ohio in 1968, police could only stop-and-frisk, a criminal search and seizare, pedestrians with probable cause that the individual(s) had committed a crime, was committing a crime, or posed a danger to the officer and/or public (Cole 1999: 17; Hamis 1994a: 660; Hamis 1997a: 660; Saleen 1997: 456; Ogletree, Jr. et al. 1995: 23). Terry allowed police to stop an individual for questioning and frisk them, conduct a cursory pat down of their clothing, upon reasonable suspicion that criminal activity was taking place or imminent, and to locate weapons (Harns 1994a: 660; 1994b: 5). Terry allowed substantial state intrusion into citizens' right of locomotion (Harns 1994a: 663) and paved the way for police practices that violate the personal and physical safety of individuals stopped under reasonable suspicion (Maclin1998: 1278) and increased the number of arbitrary stops and frisks (Rudovsky 2002: 33). Reasonable suspicion in pedestrian stops allowed police to base stops more on discretion and deference, primarily in the backstage, than on observance of crime. Discretion entails how police define and exercise law enforcement functions while deference is the vast leeway, or lack of recognition of constitutional and human rights, courts grant police (Magee 1994: 173). The fewer restrictions on how police interact with citizens, the greater, and more extensive, their discretion (Brooks 1997: 151).

In 1968, Sibron v. New York and Peters v. New York upheld the right to stop-and-frisk an individual(s) if police had reasonable suspicion that criminal activity was occurning or imminent and/or that danger existed to the officer and/or public (Saleen 1997: 459). This ruling concumed with Terry and reinforced the move from probable cause to reasonable suspicion. Stop-and frisks were to occur in matters of criminal activity and safety only and not as investigatory searches for evidence of other crimes or potential crimes (459). Police stop-and-frisks appear to be custodial arrests in which pedestrians do not feel free to leave.

Minority perestrian/motorist's reasonable-person standard of when they feel free to end a police encounter differs from the reasonable-person standard of most White pedestrians/ motorists (Cole 1999: 26-7). Minorities stopped by police feel less inclined to walk away from an encounter due to prior negative police experiences (i.e., they fear for their safety). Latina/os are subject to police stops (Fagan \& Davies 2000; Spitzer 1999; Walker 2001) and anests at rates disproportionate to their 


\section{Ethnic Studies Review Volume 30: 1\&2}

percentage of the population (Carter 1986; Petersilia 1983) and shot and killed by police twice as often as Whites (Geller 1988). Minorities who live in police-designated "high crime areas" have high stop-and-frisk rates and some attempt to evade police. Location coupled with evasion results in increased stops and frisks of minorities (Harns 1994a: 660 and 681). Minorities who fear police cannot walk or nu from police as walking or nmning from police now constitutes reasonable suspicion for a stop-and-frisk (Thaman 2000: 1006).

Therefore, police can use greater coercion against minorities than Whites during stops as minorities may feel they are under custodial arrest (i.e., full seizure). Scholars have argued that police, as representatives of the state, have the right to the legitimate use of force and legitimate use of coercion (Brown: 181). The courts have failed to limit police discretion or clearly distinguish between legitimate and illegitimate use of force and coercion.

\section{POLICE RACIAL PROFILING}

The Fourth Amendment prohibits police stopping or detaining a person unless they have reasonable suspicion the individual is involved in criminal activity. The courts, however, allow police to utilize motorist and pedestrian stops as pretext to seek evidence of crime (Milovanovic \& Russell 2001: 28). These stops are controversial but courts have upheld their constitutionality. Police have wide discretion to conduct stops in which unlimited discretion increases the opportunity for discriminatory practices (Walker, Spohn, and DeLone 1996: 101). PRP extends beyond uncomupted traffic/pedestrian stops. Driving while Brown or Black may be the excuse for a motorist stop and walking while Brown or Black can be the excuse for PQSFE.

PRP assumes that the majority of drug offenders and gang members are minorities (Harris 1999: 2-4). These assurnptions derive from police evaluations of the moral character of people they interact with and transfoming these evaluations into distributive justice (Brooks 1997: 153; Van Maanen 1974). PRP, especially drug courier profiling, is distributive justice aimed at Blacks and Latina/os (Allen-Bell 1997; Harris 1999: 3-5). Funthermore, when police focus drug enforcement polices on Blacks and Latina/os and stop them for street sales of crack and heroin while overlooking White drug dealing, they logically find a disproportionate number of Blacks and Latina/os, and a minimal number of Whites, using and dealing drugs (Harris: 3). Police perceptions of minorities as criminal (i.e., involved in gangs, and drug use/dealing) leads to more stops of minority drivers and more PQSFE of minority youths. These perceptions result in crimes committed by Whites (i.e., manufacturning and selling ecstasy and methamphetamines) going unnoticed by police (Hamis: 3 and 6-8). Furthemore, police stereotyping of minorities as "criminal" results in paranoia in individuals negotiating public spaces (Austin 1992: 173).

Police use the CARD (class, age, race, and dress) system to identify and label youth as gang members. Gang profiling associates minority youths with a set of descriptors, photographing them, and placing their names and photos in a database of known gang members (Villaruel et al. 2004: 95- 
6). A youth's class, age, race, dress, neighborhood, and socializing in a specific area does not mean he/she is a gang member (Reynoso 2002: 301). Such stops of youths constitute harassment as police stop youths for fitting a racial profile and not for criminal activity or suspicion of criminal activity (301).

Police stop minority pedestrians/motonists for being "in the wrong neighborhood." The use of the "out-of-place" doctrine posits that individual's race (i.e. skin color) is justification for pedestrian/motorist stops if they are in a predominantly White neighborhood (Russell 1998: 38). This practice involves police stereotyping of minorities and backstage decision-making that has backstage harms due to racial harassment. Race, not place, or clothing, is the primary reason for police use of CARD and out-of-place stops. When race is the main deteminant for stops, minorities face a harsher set of laws than Whites and the Equal Protection Clause' forbiddance of race-based classification is violated(Allen-Bell 1997: 217-8; Larrabee 1997: 305).

These police attitudes and practices transmit deep costs to society. PRP rarely targets Whites in middle- and upper-class neighborhoods (Ogletree, Jr. et al. 1993: 21). Judgments derived from stereotyping and backstage decision-making result in placement of deviant cultural and social attnibutes on minorities. There is a subsequent increase in motonist/pedestrian stops, anests, prosecutions, and sentencing disparity with White offenders $(86,94)$. Racial alienation, community distrust of police, and racial hoaxes (i.e., Whites blaming minorities for a crime to defer the blame from the real criminals) are further negative consequences of police stereotyping (Russell 1999: 730). Minority communities have low positive perceptions of, and trust in, police and these perceptions increase with PRP (Tyler 2002). Minorities may genuinely fear cooperating with police (Harns 1999: 268). For instance, minorities may view police authority as illegitimate due to previous negative encounters and this may affect their compliance with police (Tyler \& Huo 2002; Lind \& Taylor 1988; Reitzel et al 2004).

Minority youths innocence diminishes as they realize they do not possess equal citizenship with White youths. Minority pedestrians/motonists may be subjected to brutality, but more often to police microaggressions (i.e., personal affronts) and magroaggressions (i.e., group affronts) (Russell 1998: 138-9). Microaggressions are "subtle, stumning, often automatic and non-verbal exchanges which are "put downs" of minoritics by Whites while macroaggessions are "attacks, insults, or pejorative statements made against Blacks" or other minorities (138-9). A 1995 NAACP study on police conduct in minority communities found that verbal abuse, disrespertful conduct, and harassment of stopped minorities was rampant (Ogletree, Jr. et al.: 40-1). Micro- and macroaggressions derive from police stereotyping and backstage decisions on whom to stop and the treatment they receive. Micro- and macruaggressions dehumanize minorities as criminals and open the door to police brutality (Cummings 1998: 408). 


\section{POLICE BRUTALITY IN SAN JOSE}

San Jose, with a population of 894,943 in 2000 (City of San Jose, 2005a), has been touted as the "safest lange city in the United States" and ranked "safest American city with a population over 500,000" in 2003 and 2004 (laborlawtalk.com 2005). However, San Jose has a history of police brutality and many minority citizens fear police and fail to report crimes, and/or fail to assist police investigations (Geilhufe 1979; Holmes 1998; Huang \& Vaughn 1996). The San Jose Police Department's developed a reputation for racism and brutality in the 1960s and 1970s (Christensen 1997: 7). The police killing of chemist John Henry Smith, Jr. in 1971 enhanced this reputation (Christensen 1997). San Jose police officer Rocklin Woolley stopped Smith, a thirty-seven year-old Black man, for making an illegal u-tum (Stuchinsky 1996). Woolley reported that Smith was angry and exited his vehicle brandishing a tire iron. Woolley was unable to subdue Smith though he reportedly attempted to do so with chemical spray and his police dog. When Smith ran toward his apartinent complex, Woolley shot him in the back. Witnesses reported Smith yelling, "Help me, I'm afraid" before being shot (Stuchinsky 1996). Police Chief Robert Murphy stated that Smith was probably under the influence of drugs or alcohol though a autopsy indicated that Smith was under the influence of neither (Stuchinsky 1996).

In 1976, San Jose police officers investigating a domestic violence complaint shot and killed Danny Trevino (Chnistensen: 7). According to police, Trevino was reaching for a gun (never found) when shot. The officers did not have charges brought against them. The Chicana/o community protestod and Police Chief Murphy was fired (7).

In 1994, a Santa Clara Sheriff's Deputy stopped thirty-eight year-old Arthur Diaz behind a convenience store. Diaz had outstanding traffic warrants and it is uncertain why he began nunning. According to a witness, while Diaz was nmning down the sidewalk with his arms up the deputy's vehicle ran him down from behind and then backed over him. Diaz did not have a wespon, had not committed a crime, and had not threatened anyone (Stolen Lives Project 1999). The Califomia Highway Patrol found that the physical evidence and physicians' reports did not support the deputy's statement that Diaz ran into his car (Stolen Lives Project, Justice for Rudy 2004). Charges were not brought against the deputy.

In 1996, Santa Clara County Deputy Sheriff Tom Langley shot and killed Gustavo Soto-Mesa (Human Rights Defense Committee 2001). Soto-Mesa, a suspected drunk driver, refused to stop his vehicle and led the deputy on a four-mile chase that ended when Soto-Mesa crashed his vehicle into a parked boat-trailer (PORAC Legal Defense Fund 2000). Soto-Mesa crawled out of his wrocked vehicle and began to walk away from Langley when shot. Langley originally claimed he dropped his gun and it discharged killing Soto-Mesa. Langley later said his gun discharged while attempting to grab Soto-Mesa's shirt. The hammer of his gun cocked when it caught on his badge and fired when the trigger caught on the pen in his breast pocket (PORAC Legal Defense Fund). Witnesses claimed Soto-Mesa's death was an "execution-style killing" (Stolen Lives Project). A grand jury cleared Langley of any wrongdoing. The Human Rights Defense Committee formed in response to the killing and remains active (Sandler 1996). 
In 1999, San Jose Police Officer Robert Reichert brtally beat nineteen year-old Aaron Rivera. Rivera had been attending a downtown Cinco de Mayo celebration when police, searching for a suspect who had hit another man and stolen his jacket, approached Rivera. Rivera ran to "avoid being stampeded by a crowd of people rushing toward him" from the conclusion of a concert at HP Pavilion (Zapler 2003). Police claimed Rivera had purposefully fled, was holding a long metal pipe, and fought with officers. Reichert hit Rivera numerous times with his baton fractuning Rivera's skull and breaking one of his ams (Zapler 2003: 1).

Rivera never became a suspect in the jacket theft and a jury acquitted him of unlawful assembly, carrying a concealed weapon (no pipe was found), and deadlocked on the charge of resisting arrest. Rivera was guilty of fleeing from the police and given three years probation, forty-five days community service, and a $\$ 1,000$ fine. Rivera sued the city and was awarded $\$ 390,000$ in damages in 2003, though San Jose Police Chief Bill Lansdowne disagreod with the decision to settle the lawsuit. Lansdowne claimed, "It was my position that we should have tried that case and we could have won" (Zapler). The city did not change Reichert with any crime. Reichert had gained notoriety for the fatal shooting of an amed motorist in 1997 and for threatening a Santa Clara County Jail inmate. San Jose/Silicon Valley NAACP Chairman Rick Callender claimed that Reichert had "proven to be dangerous. There is no way he should be a police officer anywhere in our nation" (Zapler: 1).

In 2003, police responded to an unsupervised child wandering in the street call. Upon anival, the child was inside his home, which police entered Within seconds of entering the home, San Jose Police Officer Chad Marshall shot and killed twenty-five ycar-old Cau Bich Tran (Bay City News 2005). Tran, a 4'll' $90 \mathrm{lb}$ mother of two, had also called police to assist her in gaining entry to a room she had locked herself out of (Bay City News 2005). Tran had tried to "jimmie" the lock with a dao bao, a Vietnamese vegetable peeler, which police believed was a cleaver she was attempting to throw at them when shot (Asian Pacific Islander Legal Outreach 2003).

In 1999, there were twenty-five homicides in San Jose, of which seven were civilians who died from police shootings (Justice for Rudy 2004). The San Jose Human Rights Defense Committee compared data on "Fatal Police Shootings per 100,000 Residents" and "Homicide Rate per 100,000 Residents" from 1990-1997 for the twenty-seven largest U.S. cities. San Jose ranked fourth of the cities in fatal police shootings per 100,000 residents with 0.9 per 100,000 compared to the national average of 0.5 per 100,000 residents.

San Jose's rate of three homicides per 100,000 residents was the lowest of the twenty-seven cities. The three cities with higher rates of fatal police shootings per 100,000 residents were Washington, D.C.; Detroit; and Baltimore. These cities claimed their high fatal police shooting rates were due to high crime and homicide rates of 72 per 100,000 residents in Washington, D.C.; 55 per 100,000 residents in Detroit, and; 46 per 100,000 residents in Baltimore (Justice for Rudy 2004). San Jose's homicide rate is low so the rate of fatal police shootings per 100,000 residents might be expected to 
be low. However, between 1990 and 2000, San Jose had the highest ratio of killings by police compared to overall homicide rate of the fifty largest U.S. cities (Maiden 2005a).

\section{INITIAL STUDY OF TWO TACO BELLS: METHODOLOGY}

\section{Benchmarking and Sampling}

In analyzing data on police vehicle stops, it is important to use companison groups to create a benchmark to measure against stop data This requires comparing the demographic profiles of motorists stopped by police to the demographic profiles of:

1. Local residents.

2. Residents with a driver's license.

3. People observed driving (Fridell 2004: 7).

This study examined pedestrian stops so there was no need for the demographic profiles of residents with a driver's license and those "observed driving" becarne those "observed walking." The demographic profiles of pedestrians took on less importance than the profiles of motorists. All pedestrians were local residents.

The study's intent was to examine racial bias, not necessarily gender or class bias, in stops. Benchmarking developed a racial/ethnic profile of individuals who should be at the highest risk of PQSFE, assuming no bias. This study rocorded the ethnicity of youth pedestrians:

1. Stopped at/near TBs.

2. At/near TBs.

3. Stopped in Business Districts.

4. In Business Districts

The author conducted verbal surveys at twenty TB restaurants from October 2002 to January 2004. The survey sample consisted of 750 youths between the ages of twelve to twenty-five. The ethnicity of individuals stopped at/near TBs and, later, the ethnicity of individuals stoppod in San Jose business districts were recorded. Pedestrian youths reported the number of times they:

1. Patronized TBs monthly.

2. Were stopped for questioning by SJPD Officers.

3. Were stopped-and-frisked by SJPD Officers.

4. Patronized TBs.

A benchmark compared the number and ethnicity of youth pedestrians at/near TBs to the number of youth pedestrians stopped by police at/near TBs. Recording the number of youth pedestrians by ethnicity and stops in business district created a further benchmark Weaknesses of the survey method included respondents' inability to recall when a police stop occumed 


\section{Research Design and Variables}

This is an ex post facto comparative mixed design study with between-groups attribute independent variables of race/ethnicity and gender and dependent variables of number of police questionings over the previous twelve months, number of police stop-and-frisks over the previous twelve months, and total PQSFE over the previous twelve months. Gender is a within-subjects independent variable with two levels, male and female. Comparisons were made between police questionings, stop-and-frisks, and total PQSFE between race/ethnicity and males/females. Companisons were made of police questionings, stop-and-frisks, and total PQSFE within race/ethnicity by gender.

\section{Hypotheses to Explain Discrepancies in PQSFE by Ethnicity}

There are five hypotheses for the existence of discrepancies in the percentages of pedestrians stopped by ethnicity. The first hypothesis is that police use racial bias in stop decisions (Fridell, 2004, p. 2). Fridell's competing hypotheses for why police stop minority drivers at a higher rate than White drivers are that racial/ethnic groups are not equally represented:

1. As residents in the junisdiction.

2. As drivers on junisdiction roads.

3. In the nature and extent of their pedestrian law- violating behavior.

4. As drivers where stopping activity by police is high (12).

These hypotheses focused on motorist stops but were revised to analyze pedestrian stops. To conclude if racial bias was a factor in stops, the research must discount all other explanations for dispanty. Analysis and interpretation of stop data would include all factors in the altemative propositions outlined by Fridell (12). The first competing hypothesis, "racial/ethnic groups are not equally represented as residents in the jurisdiction" compares census data of the racial/ethnic population of San Jose with the ethnicity of youth pedestrians stopped.

The second competing hypothesis, "racial/ethnic groups are not equally represented as drivers on junisdiction roads" changed to "racial/ethnic groups are not equally represented as youth pedestrians on jurisdiction sidewalks/pathways." If the focus is on the second hypothesis, there is no need to address the first. If we know who motorists are then we need not know who lives in the neighborhood (Fridell: 12). Pedestrians were those who lived in the neighborhood. The primary factor detemined through this revised hypothesis was if the percent of pedestrians from an ethnic/racial group was different from their representation in the local community.

The third competing hypothesis, "racial/ethnic groups are not equivalent in the nature and extent of their traffic law-violating behavior" becarne "racial/ethnic groups are not equivalent in the nature and extent of their pedestrian law-violating behavior." Data on pedestrian law violating (i.e., failure to comply with traffic signals and jaywalking) came from observation. 
Competing hypothesis four, "racial/ethnic groups are not equally represented as drivers on roads where stopping activity by police is high" became "racial/ethnic groups are not equally represented as pedestrians on sidewalks/pathways where police stopping activity is high." Tracking pedestrians' ethnicity allowed analysis of this hypothesis for youths: Stopped at/near TBs; At/near TBs; Stopped in business districts, and; In business districts.

\section{The SJPD "Vehicle Stop Demographic Study"}

In 2000, the SJPD became the first Califomia police agency to conduct yearly motorist studies in which the Crime Analysis Unit (CAU) recorded the ethnicity of stopped individuals and division stopped in. The computer-aided dispatch system (CAD) electronically records data after police complete vehicle stops (SJPD 2002). The most recent year for which data is available is 2001. The SJPD study noted the following "Dilemmas Presented When Collecting and Analyzing the Data":

1. Analysis is Based Upon Total San Jose Population Instead of Driver Population. The ethnicity of stopped drivers compared to the ethnicity of San Jose's total population and not the total driver population or the number and ethnicity of drivers at the time of stops.

2. Non-San Jose Drivers Included in Study.

3. Potential Exists That Some Drivers Accounted for Multiple Stops.

4. Downtown Cruising Could Account for Numerous Vehicle Stops (SJPD 2002).

This study avoided the "dilemmas" of the SJPD Vehicle Stop Demographic Study. The study compared the ethnicity of youth pedestrians subjected to PQSFE at/near TBs to the ethnicity of San Jose's population. The study made companisons between ethnicity of youth pedestrians: at/near TBs; of those stopped in business districts, and; those in business districts.

All pedestrians were local residents. Pedestrians did not account for multiple stops and counted as having only one questioning or stop-and-frisk within the last twelve months. The study never counted pedestrians as having multiple stops though this might have indicated lesser or greater PQSFE rates by ethnicity. Motorist cruising was not a factor in this pedestrian study.

The SJPD study found the following percentage of motonists stopped by ethnicity compared to each ethnicity's percentage of San Jose's population:

1. Asian American: 16 percent of stopped 26.9 percent of population.

2. African American: 7 percent of stopped, 3.5 percent of population.

3. Hispanic American: 41 percent of stopped, 30.2 percent of population.

4. Other. 5 percent of stopped, 3.4 percent of population.

5. European American: 31 percent of stopped, 36 percent of population (SJPD 2002).

African Americans accounted for twice the pcrcentage of stops as their percentage of the population, whereas Hispanic Americans accounted for significantly more stops than their percentage of the population. Nevertheless, the SJPD claimed, "there is not a racial profiling problem in the city of San Jose" (SJPD 2002). The report defended this view arguing: 
1. Stop rates were higher for Hispanics and African Americans because there were more calls for police service and more officers-per-capita in smaller police districts with higher concentrations of minorities. Hence, there would be more stops. This does not explain why, or for what reason, more calls for police service were requested or if overpolicing occurred.

2. The percentage of stops by ethnicity in each district comesponded to their percentage of that districts' population. (This is a better measure but does not account for discrepancies between ethnic groups' stop percentage and their percentage of the city's population).

3. The SJPD received only 17 official complaints of motorist stops due to racial profiling. (This neglects that many citizens will not file complaints due to fear of police and belief that police will not investigate complaints).

4. The percentage of motorists stopped by ethnicity is less important than the number of motorists stopped by ethnicity. (This argument makes no sense as percentage and number of motorists stopped by ethnicity result in the same number of stops)(SJPD2002).

\section{PILOT STUDY}

Convenience sampling was used in selecting two groups to determine if PRP of Chicana/o youths at/near San Jose TBs existed: Chicana/os and Whites between the age of twelve to twenty-five. Surveys took place at two $\mathrm{TBs}^{1}$ on a Friday and Saturday between $8 \mathrm{pm}$ and $11 \mathrm{pm}$ when police reported gang activity was highest. Respondents were questioned conceming their racial identification, age, residency (if they were San Jose residents), frequency of TB visits, and if they had been questioned or stopped- and-frisked by the police at/near TBs within the preceding twelve months. The survey included 15 Chicana/o and 15 White patrons surveyed at each location for a total of 30 Chicana/os, 15 males and 15 females, and 30 Whites, 15 males and 15 females (60 individuals). The survey consisted of respondents between the ages of twelve to twenty-five, those police were most likely to stop. Furthermore, ninety-five percent of customers between the hours of $8 \mathrm{pm}$ and $11 \mathrm{pm}$ were between the ages of twelve to twenty-five. 


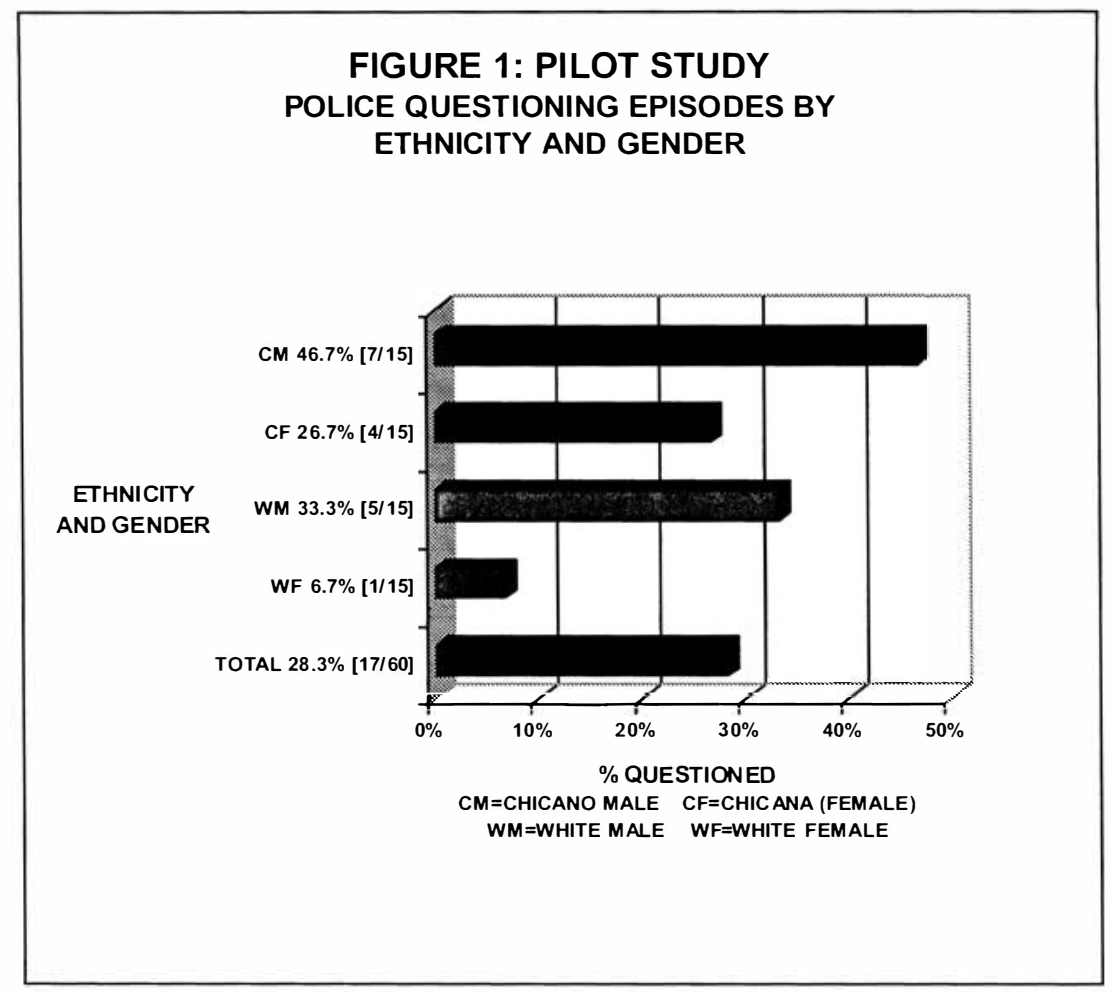

Each customer gave his or her ethnic identification and age when entering each TB.

Seventeen youths claimed they had been questioned at/near TBs by San Jose police and six claimed they had been patted-down (statistics are for episodes over the preceding twelve months). The author did not count the seventeen youths who claimed police questionings again under pat downs and vice versa. Pedestrians who reported police stops and questionings count only as questioning episodes while individuals who reported stops, questionings, and pat-downs count only under stopand-frisk episodes. Patting-down moved the incident out of a questioning into a stop-and-frisk. Stop-and-frisks do not count as questionings. Episodes are séparate except when tallied as "total police episodes." Twenty-eight point three percent of respondents reported police-questioning episodes and 10 percent stop-and-frisk episodes. The percentage of individuals reporting being questioned, stopped-and-frisked, and total by ethnicity was:

- Chicana/o: 36.7 percent questioned, 16.7 percent stopped-and-frisked, 53.3 percent total.

- White: 20 percent questioned, 3.3 percent stopped-and-frisked, 23.3 percent total. 


\section{Koehler - Police Racial Profiling}

The percentage of individuals reporting being questioned, stopped-and-finsked, and total by ethnicity and gender was:

- Chicano males: 46.7 percent questioned, 26.7 percent stopped-and-frisked, 73.3 percent total.

- Chicanas: 26.7 percent questioned, 6.7 percent stopped-and-frisked, 33.3 percent total.

- White males: 33.3 percent questioned, 6.7 percent stopped-and-frisked, 40 percent total.

- White females: 6.7 percent questioned, 0 percent stopped-and-frisked, 6.7 percent total.

Figures 1 (questionings), 2 (stop-and-frisks), and 3 (total police episodes) show the number and percentages of reported episodes by "ethnicity" and "ethnicity and gender."

\section{FIGURE 2: PILOT STUDY \\ POLICE STOP-AND-FRISK EPISODES BY \\ ETHNICITY AND GENDER}

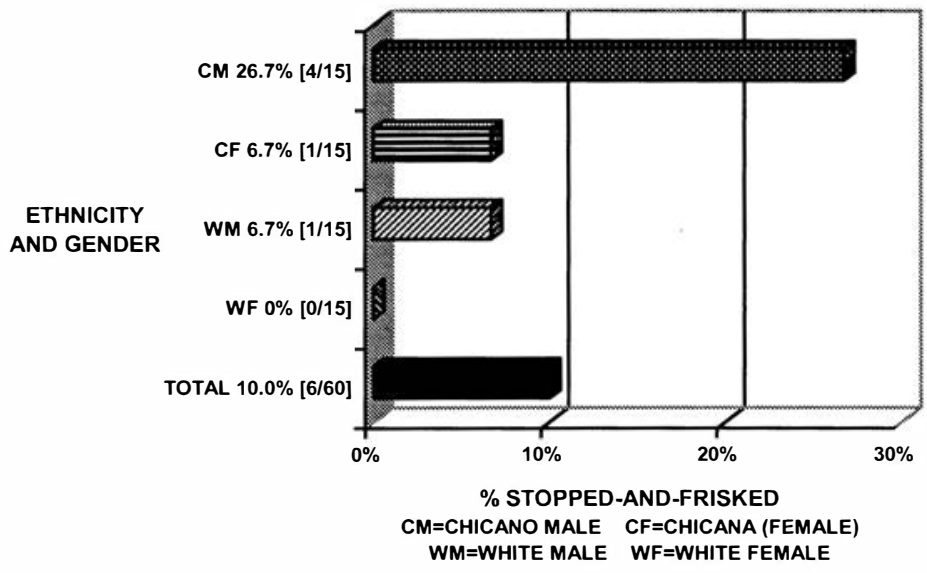




\section{FIGURE 3: PILOT STUDY \\ TOTAL POLICE EPISODES BY ETHNICITY AND GENDER}

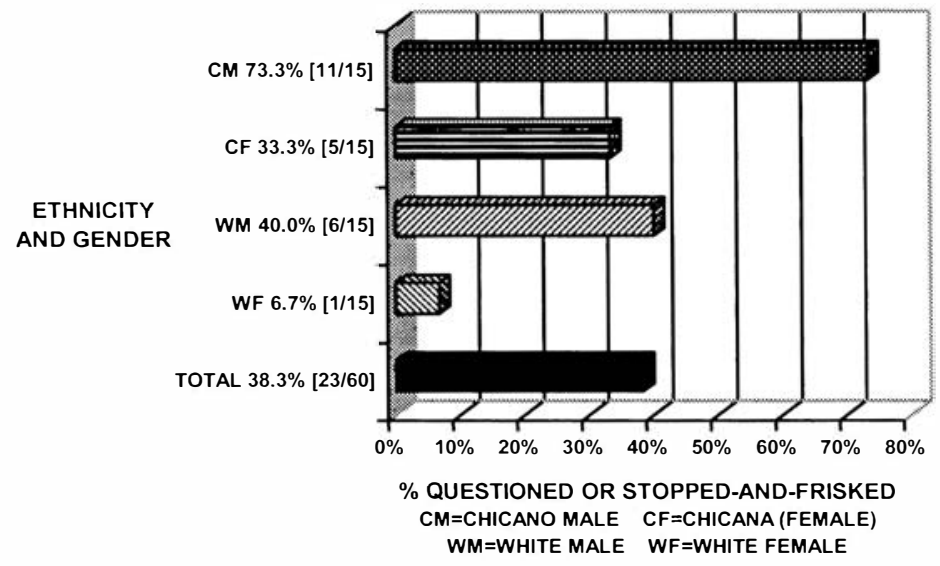

Individuals twenty-six and over comprised approximately 4 percent of customers and those under the age of twelve comprised less than 1 percent. Ninety-five percent of customers were between the ages of twelve to twenty-five. The percentage of customers between the ages of twelve to twentyfive by ethnicity was:

- White: 61 percent

- Chicana/o: 32 percent

- Asian American: 5 percent

- African American/Other: 2 percent

Youths patronized TBs the following number of times per month by ethnicity:

- White: 4.3

- Chicana/o: 3.1

- Asian American: 2.4 
Koehler - Police Racial Profiling

- African American/Other: 3.4

Whites were the highest percentage of youth customers and patronized TBs most frequently.

\section{EXTENDEDSTUDY}

Eighteen additional TBs were randomly selected (in predominantly White, Chicana/o, Asian American, and mixed neighborhoods) to examine the existence of PRP. The author recorded respondents' age, ethnic/racial identification, residency, frequency of TB visits, and police contacts at/near TBs in the preceding twelve months. The extended study used the same field research methods and questions, with the addition of a sample of 150 Asian American youths, primarily Vietnamese Americans. San Jose has the largest Vietnamese American population of any U.S. city with 78,842 or 8.8 percent of the city's population (City of San Jose, 2005a). Surveys took place at two TBs per weekend (Fridays and Saturdays) from $8 \mathrm{pm}$ to $11 \mathrm{pm}$ and sometimes until lam. Three hundred Chicana/os, 300 Whites, and 150 Asian Americans between the ages of twelve to twentyfive were verbally surveyed (750 individuals including the pilot study). An equivalent number (150) of females and males in the Chicana/o and White samples were surveyed (75 each for Asian Americans) to determine if gender factored in PQSFE.

The total number of respondents does not reflect the number of attempted surveys as approximately 5 percent of customers declined participation. The author recorded the number of attempted surveys, those surveyed, and the number of customers as they entered TBs. In addition, each customer's recorded age and ethnicity established a benchmark to compare with those pedestrian customers who claimed to have been questioned or stopped-and-frisked. The majority of customers between 8pm and $11 \mathrm{pm}$ on Friday and Saturday nights, more than 90 percent at each TB, were pedestrians. Youths chose TBs over local taquerias as TBs were inexpensive and provided quick service. Less than five percent of TB youth patrons drove vehicles to the restaurant. They answered the same questions as pedestrians. The majority of youth motorists patronized TBs as pedestrians numerous times within the preceding twelve months and, therefore, counted in the pedestrian sample and several claimed police stopped and questioned them while walking to their cars after exiting TBs. Chicana/o youths reported being stopped much more frequently leaving TBs than while walking to TBs. Similarly, minority youth pedestrians in business districts reported stops more frequently when leaving business districts than when walking to business districts. When minority youths completed their consumer exchanges, their presence in regions of spatial economy transformed from acceptance to prohibition. Businesses desired their spending but not their continued presence. The data served as a second benchmark to compare with TB data. The same methodology applied to data collected in business districts located at least one mile from TBs. This cnsured a different sample of pedestrians. 


\section{FIELD RESEARCH RESULTS}

\section{Ethnicity}

The percentage of individuals reporting being questioned, stopped-and-frisked, and total by ethnicity was:

- Chicana/o: 37.3 percent questioned, 13.7 percent stopped-and-frisk, 51 percent total.

- White: 8.7 percent questioned, 2.3 percent stopped-and-frisked, 11 percent total.

- Asian American: 13.3 percent questioned, 10.0 percent stopped-and-frisked, 23.3 percent total.

\section{FIGURE 4: EXTENDED STUDY POLICE QUESTIONING EPISODES BY ETHNICITY AND GENDER}

ETHNICITY AND GENDER

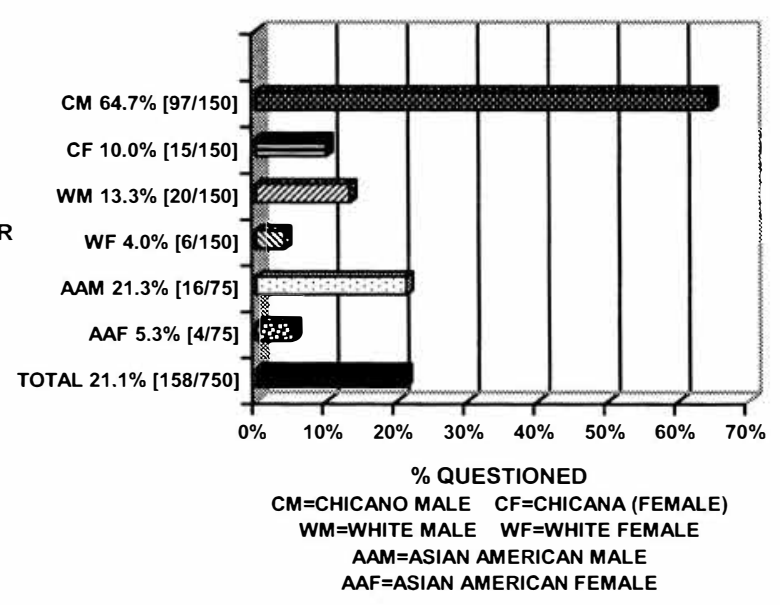

Again, individuals' police episodes counted as either questionings or stop-and-frisks (See figures 4, 5, and 6). Respondents' episodes did not count as both questionings and stop-and-frisks. Only when tallied as total episodes were they combined (See Figure 9). 


\section{FIGURE 5: EXTENDED STUDY POLICE STOP-AND-FRISK EPISODES BY ETHNICITY AND GENDER}

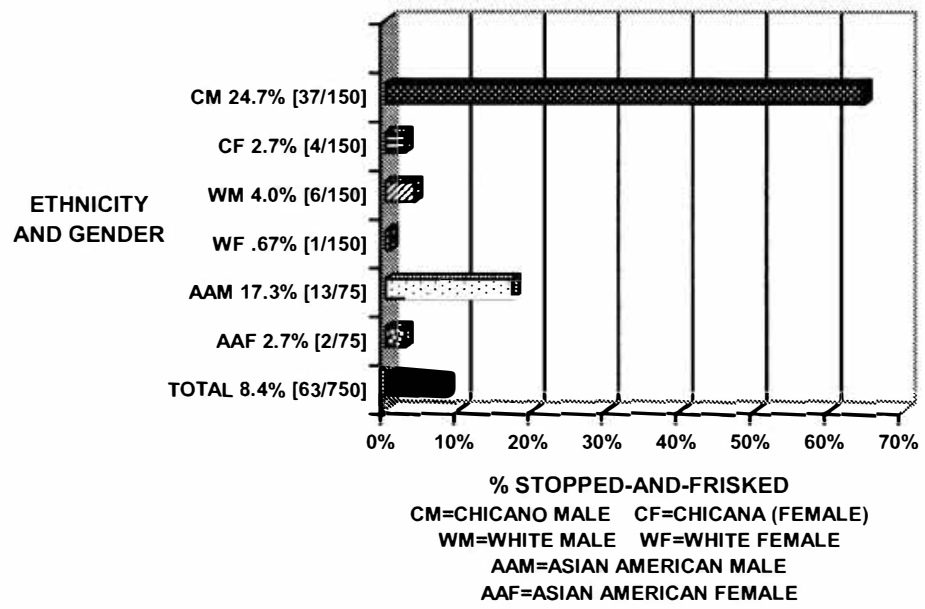

The percentage of customers between the ages of twelve to twenty-five by ethnicity was:

- Chicana/o: 22 percent

- White: 58 percent

- Asian American: 17 percent

- African American/Other: 3 petcent. 


\section{FIGURE 6: EXTENDED STUDY \\ TOTAL POLICE EPISODES BY ETHNICITY AND GENDER}

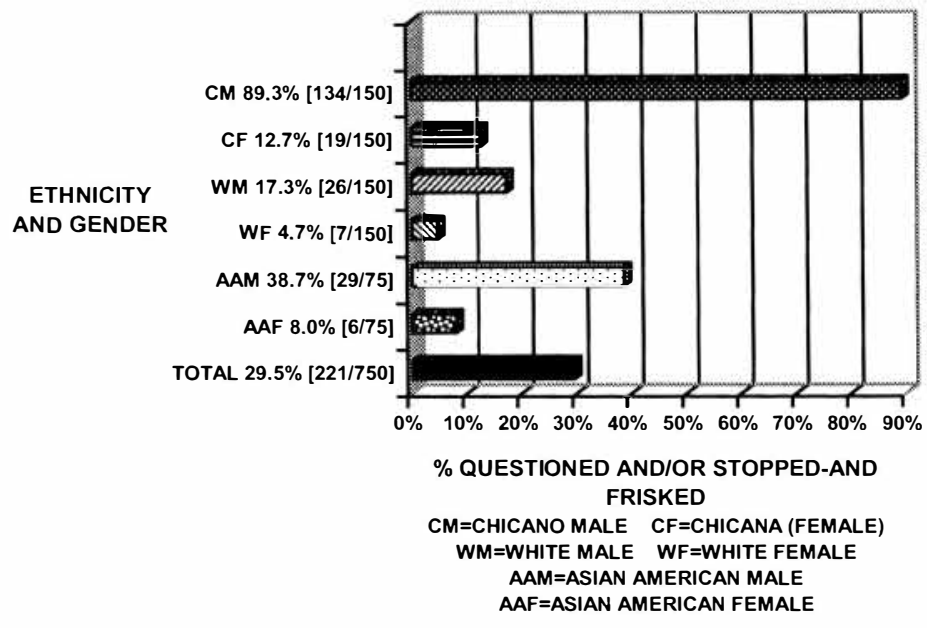

\section{Ethnicity and Gender}

The percentage of males questioned or stopped-and-frisked from each ethnic group was higher than that of comesponding females. The percentage of individuals who reported being questioned and stopped-and-frisked by ethnicity and gender was (See Figures 7 and 8):

- Chicano males: 64.7 percent questioned, 24.7 percent stopped-and-frisked, 89.3 percent total.

- Chicanas: 10.0 percent questioned, 2.7 percent stopped-and-frisked, 12.7 percent total.

- White males: 13.3 percent questioned, 4.0 percent stopped-and-firisked, 17.3 percent total.

- White females: 4.0 percent questioned, .7 percent stopped-and-finsked, 4.7 percent total.

- Asian American males: 21.3 percent questioned, 17.3 percent stopped-and-frisked, 38.7 percent total. 
- Asian American females: 5.3 percent questioned, 2.7 percent stopped-and-frisked, 8.0 percent total.

\section{FIGURE 7: EXTENDED STUDY TOTAL POLICE EPISODES AMONG MALES BY ETHNICITY}

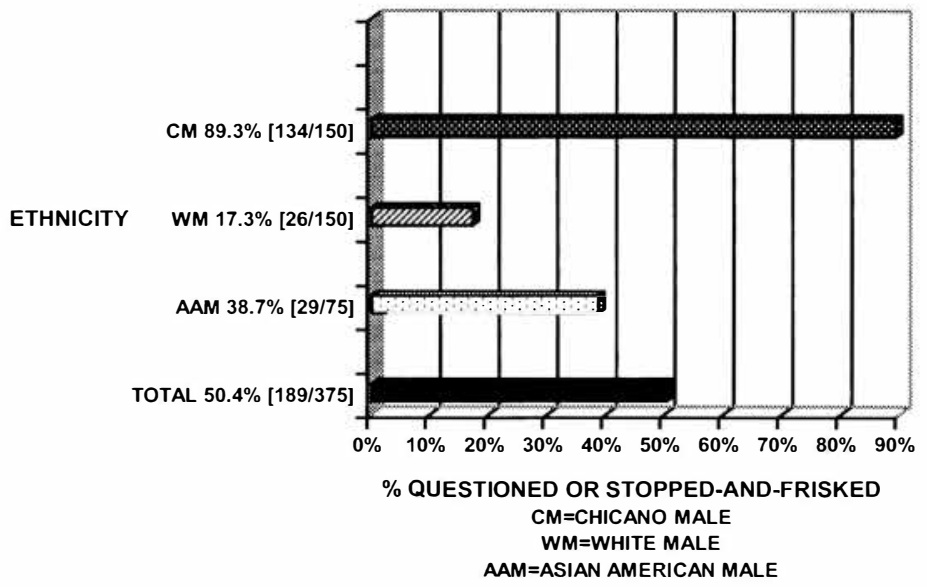

Significantly, five White male youths and one White female youth claimed police harassment due to being "poor" and/or walking to/from TBs accompanied by Chicana/os and/or Asian Americans. Gang activity was not seen other than the rare wearing of "colors." 


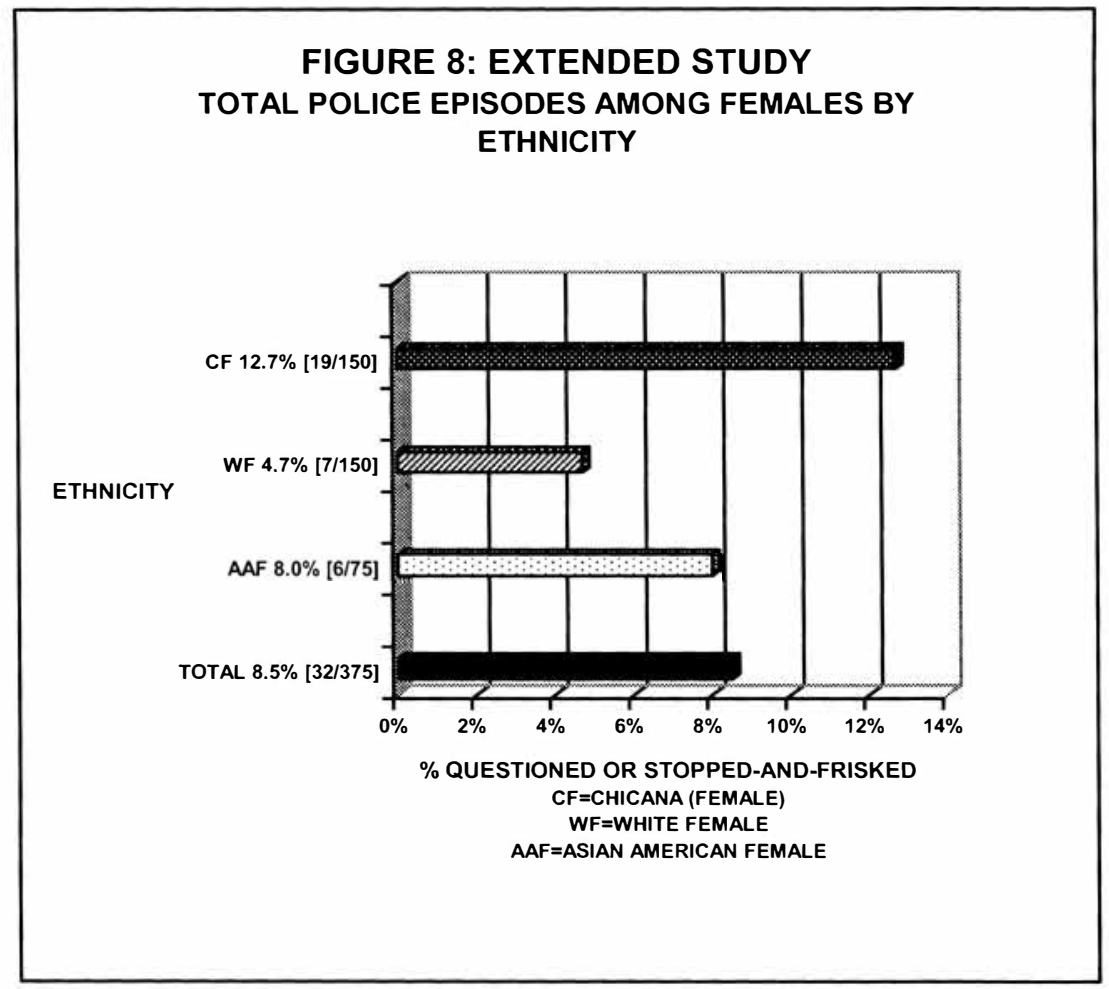

Comparison between Chicana/os and Whites showed that Chicana/os had:

1. Been Questioned 4.3 times more than Whites.

2. Been Stopped-and-frisked 5.9 times more than Whites.

3. A combined episode rate 4.6 times more than Whites.

Comparison between Chicana/os and Asian Americans showed that Chicana/os had:

1. Been Questioned 2.8 times more than Asian Americans.

2. Been Stopped-and-frisked 1.4 times more than Asian Americans.

3. A combined episode rate 2.2 times more than Asian Americans.

Chicano males had questioning rates:

1. 6.5 times more than Chicanas.

2. 4.9 times more than White males.

3. 16.2 times more than White females.

4. 3 times more than Asian American males. 
5. 12.1 times more than Asian American females.

Chicano males had stop-and-frisk rates:

1. 9.3 times more than Chicanas.

2. 6.2 times more than White males.

3. 37 times more than White females.

4. 1.4 times more than Asian American males.

5. 9.3 times more than Asian American females.

Chicanas had questioning rates:

1. 6.5 times less than Chicano males.

2. 1.3 times less than White males.

3. 2.5 times more than White females.

4. 2.1 times less than Asian American males.

5. 1.9 times more than Asian American females.

Chicanas had stop-and-frisks at a rate:

1. 9.3 times less that of Chicano males.

2. 1.5 times less than White males.

3. 4 times more than White females.

4. 6.5 times less than Asian American males.

5. The equivalent number of times as Asian American females. 


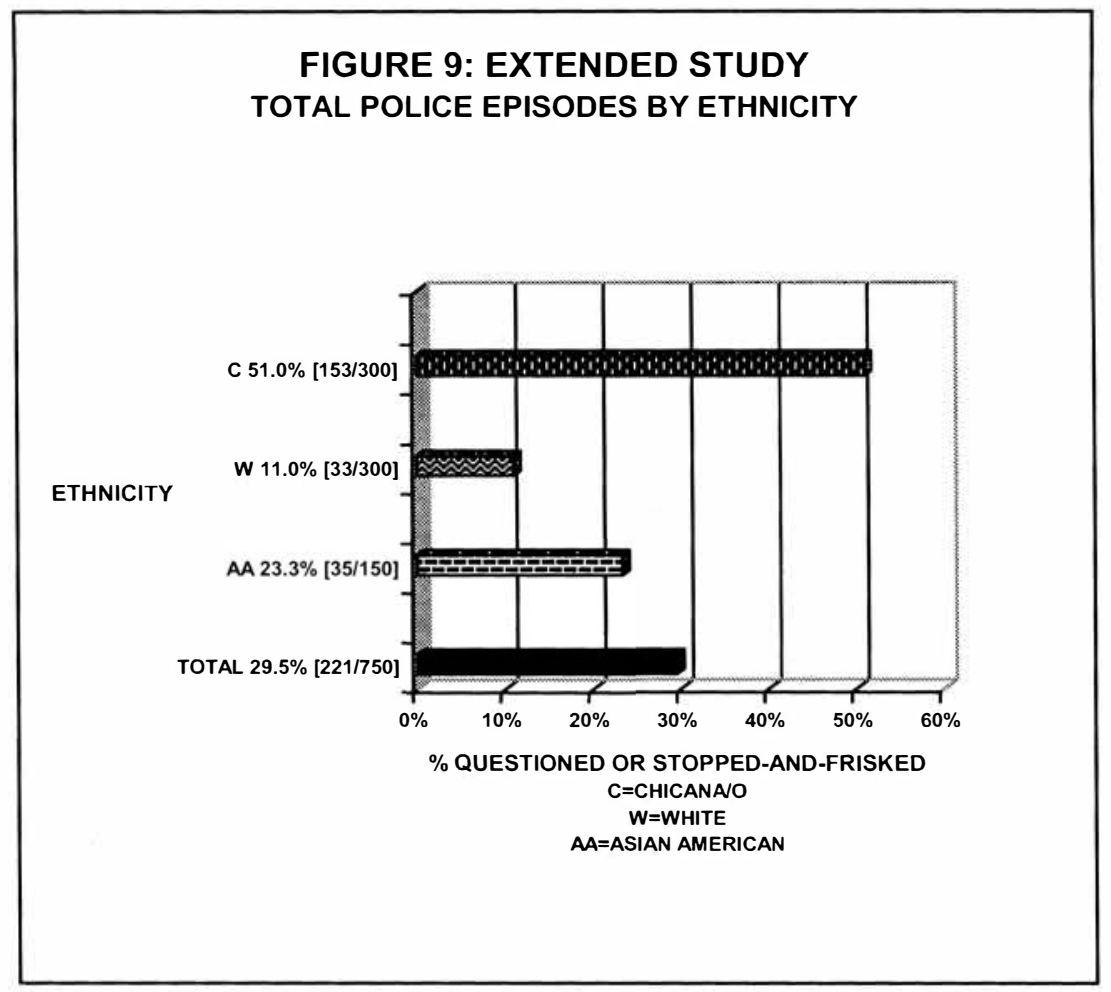

\section{OBSERVATIONS}

This research evidenced PRP. Altemative explanations seemed implausible as Chicana/os, at twenty TBs, had a questioning rate 4.3 times that of Whites and 2.8 times that of Asian Americans. Chicana/os had a PQSFE rate 5.9 times that of Whites and 1.4 times that of Asian Americans. The author obscrved approximately one dozen PQSFE of Chicana/o and Asian American youth at six TBs by White and Chicana/o police officers, thus, it seemed unlikely that Chicana/os and Asian Americans self-reported episodes that never occurned The PQSFE rate of Chicana/os and Vietnamese Americans was not the result of a few "bad apples" in the SJPD.

Ninety-three percent of TB customers were between the ages of twelve to twenty-five, five percent were over twenty-six, and approximately two percent were under the age of twelve. The percentage of customers between the ages of twelve to twenty-five by ethnicity and their corrsponding percent of PQSFE was: 
- Chicana/o: 24 percent, 69.2 percent of PQSFE.

- White: 57 percent, 14.9 percent of PQSFE.

- Asian American: 17 percent, 15.8 percent of PQSFE.

- African American/Other: 2 percent, 0 percent of PQSFE.

Youths patronized TBs the following number of times per month by ethnicity:

- Chicana/os: 3.4

- Whites: 4.9

- Asian Americans: 3.6

- African Americans/Other: 2.1

Whites were the majority of youth customers and patronized TBs most often but had the lowest PQSFE rate. Utilizing the benchmark of total TB customers between the ages of twelve to twentyfive versus individual's between the ages of twelve to twenty-five subjected to PQSFE it was evident that PRP of Chicana/o and Asian American youths is statistically evident.

\section{EXPLANATIONS FOR CHICANA/O YOUTH'S HIGH PQSFE RATE}

\section{Curfews}

One explanation for Chicano youths' high PQSFE rate was police enforcement of the youth curfew. San Jose's curfew restricts those fifteen and under from being out without parental supervision from 10:00pm to 5:00am and youths sixteen and seventeen from being out unsupervised from 11:30pm to 5:00am (SJPD 2005b). The author observed six youths under the age of fifteen violating the curfew. No youths reported police stops for curfew violation.

\section{Population by Ethnicity and Distribution}

San Jose has five police divisions (Aimort, Central, Westem, Foothills, and Southem). Each division consists of sixteen districts except for Airport, which has none and no substantial population. The Central Division is primarily Hispanic and White while Westem is primarily White with a substantial Asian American population. Foothills is primarily Hispanic and Asian American. Southem is predominantly White (U.S. Census Bureau 2000a). The median income of Hispanic households was $\$ 52,827$ but $\$ 87,486$ for White households and $\$ 80,312$ for Asian American households (City of San Jose 2005b). The highest poverty neighborhoods were predominantly Hispanic and located in all four major divisions (U.S. Census Bureau 2000b).

The percentage of Whites, Chicana/os, and Asian Americans subjected to PQSFE should have comesponded to their percentage of TB customers or, less likely, to their percentage of San Jose's population if ethnicity and pedestrian law-violating behavior were not a factor. Whites comprised 36.0 percent of San Jose's population in 2000 (City of San Jose 2005a) and approximately 58 


\section{Ethnic Studies Review Volume 30: 1\&2}

percent of patrons, but experienced only 14.9 percent of PQSFE as indicated in Figure 9. Chicana/os comprised 24.7 percent of the population (City of San Jose 2005a), 22 percent of TB patrons, and 69.2 percent of PQSFE. Asian Americans fared better than Chicana/os, as they comprised 26.9 percent of the population (City of San Jose 2005a), 17 percent of patrons, and 15.8 percent of PQSFE. The Asian American percent of PQSFE could be higher if the study included 300 Asian Americans and there was an equal distribution. In 2000, there were 177,402 San Jose residents (19.82\% of the population) between the ages of twelve to twenty-five (U.S. Census Bureau 2000c). The U.S. Census Bureau and City of San Jose do not maintain records of race/ethnicity by age except for those over the age of eighteen and under the age of eighteen so there is no way to determine the exact number of youths by race/ethnicity between twelve to twenty-five.

\section{High Crime Rates}

Police district crime statistics were analyzed to determine if Chicana/os' and Asian Americans' PQSFE rates were related to their being stopped at TBs in higher crime rate districts. The difference between Chicana/os' and Whites' PQSFE percentages were consistent in the "highest," "medium," and "lowest" crime districts:

- Highest: Chicana/os 68.9 percent, Whites 17.8 percent (See Figure 10).

- Medium: Chicana/os 67.2 percent, Whites 10.9 percent.

- Lowest: Chicana/os 71.6 percent, Whites 14.9 percent (See Figure 11). 


\section{FIGURE 10: EXTENDED STUDY}

$\%$ OF TOTAL PQSFE IN FOUR HIGHEST

CRIME RATE DISTRICTS BY ETHNICITY

(DISTRICTS L, P, X, AND A)

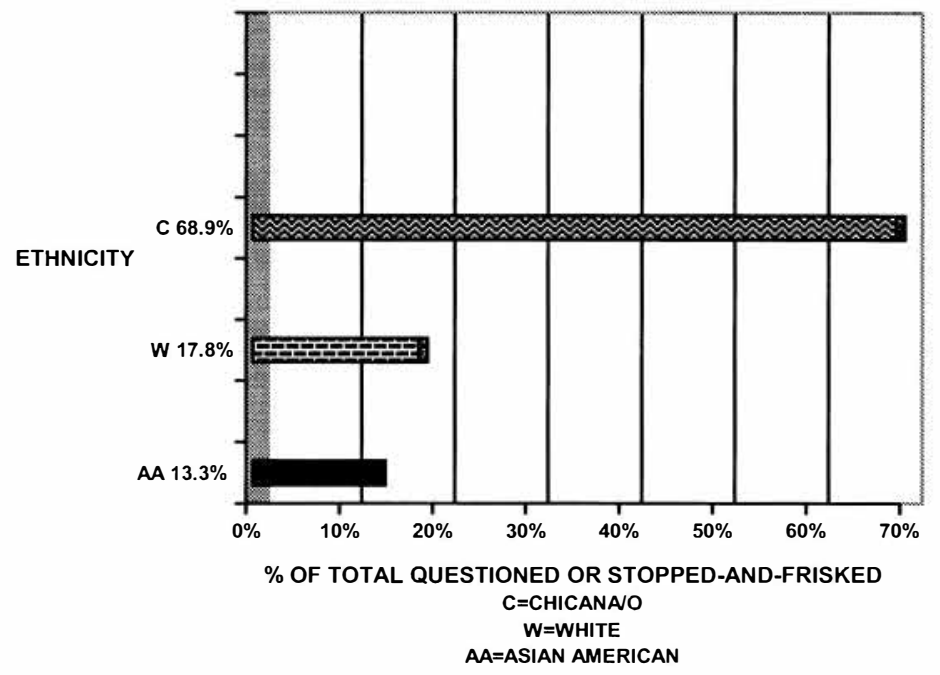

Chicana/os and Asian American PQSFE rates were higher regardless of police district in which TBs were located. The findings did not support the argument that Chicana/os only had higher PQSFE rates at TBs in high crime rate districts. As a nineteen year-old Chicano stated:

If I go to the Taco Bell on (720) Story Road (District L), I get hassled by the police. If I go to the one (Taco Bell) on (2102) McKee Road (District M) I get hassled. If I go to the one on (1298) Winchester (Boulevard), I get hassled by the police. It don't matter which one you go to. The police are watching you and at nighttime they'll stop you and ask what you are doing out. Like we (Chicana/o youths) are not allowed to be in public after dark. Maybe 'cause they (the police) can't see our Brown skin as well at night (Author 2004). 


\section{FIGURE 11: EXTENDED STUDY $\%$ OF TOTAL PQSFE IN FOUR LOWEST CRIME RATE DISTRICTS BY ETHNICITY (DISTRICTS N,M,T, AND W)}

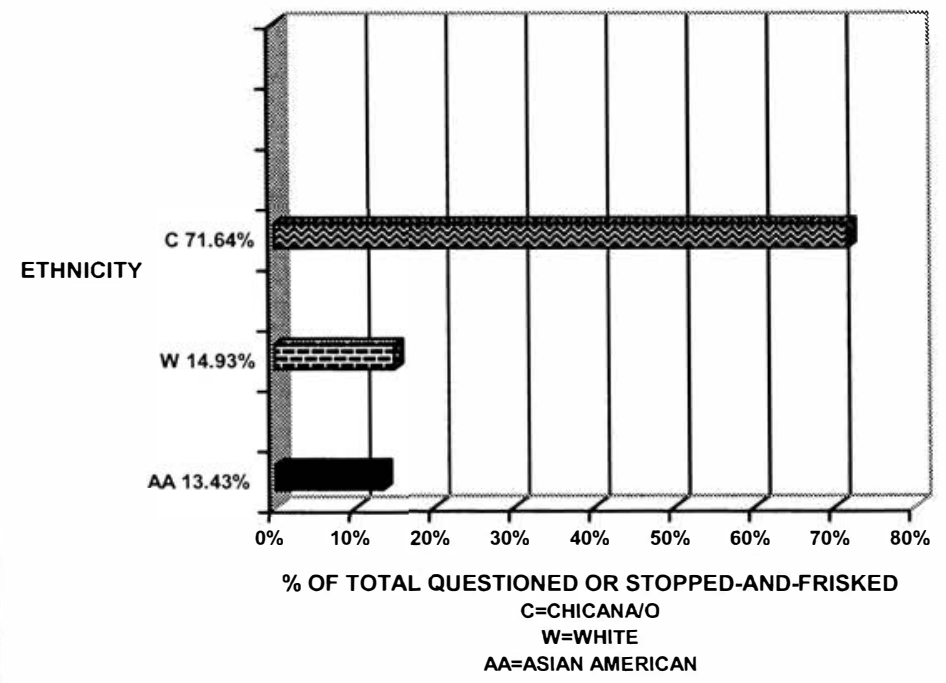

The means by ethnicity and gender were calculated for police questionings and police stop-andfrisks at/near TBs for the previous twelve months with a "yes" response scored as " 1 " and a "no" response scored as "0." The higher the mean the greater the number of individuals of that ethnicity and gender questioned or stopped-and-frisked by the police in the previous twelve months. Chicano males had the highest mean for police questionings, .6467 (SD .4796), and the highest mean for police stop-and-frisks, 2467 (SD .4325), followed by the means for both dependent variables for Asian American males and white males. White females had the lowest mean for police questionings, .0400 (SD .1966), and for police stop-and-frisks, .0067 (SD .0817). The means by ethnicity and gender are shown in Figrre 12. 


\begin{tabular}{|c|c|c|c|c|c|}
\hline \multicolumn{5}{|c|}{ FIGURE 12: POLICE EPISODES BY ETHNICITY AND GENDER* } \\
\hline Variables & Dependent & \multicolumn{2}{|c|}{ Police Questionings } & \multicolumn{2}{c|}{ Police Stapand-Frisks } \\
\hline Independent & Number & Mean & Std. Deviation & Mean & Std. Deviation \\
\hline $\begin{array}{c}\text { Chicano } \\
\text { Males }\end{array}$ & 150 & .6467 & .4796 & .2467 & .4325 \\
\hline $\begin{array}{c}\text { Chicanas } \\
\text { Females }\end{array}$ & 150 & .1000 & .3010 & .0267 & .1617 \\
\hline $\begin{array}{c}\text { White } \\
\text { Males }\end{array}$ & 150 & .1333 & .3417 & .0400 & .1966 \\
\hline $\begin{array}{c}\text { White } \\
\text { Females }\end{array}$ & 150 & .0400 & .1966 & .0067 & .0817 \\
\hline $\begin{array}{c}\text { Asian American } \\
\text { Males } \\
\text { Asian American } \\
\text { Females }\end{array}$ & 75 & .2133 & .4124 & .1733 & .3811 \\
\hline
\end{tabular}

*Means are calculated by "yes" (1) and "no" responses $(0)$ to individuals being questioned by the police in the previous twelve months and stopped-and-fiisked by the police in the previous twelve months. The higher the mean the greater the number of those individuals by ethnicity and gender questioned or stoppectand-frisked and vice versa.

\section{Benchmarking Revisited}

This study utilized two benchmarks to analyze PRP. The first benchmark was the sample of youths by ethnicity/race subjected to PQSFE measured against the total number of youth TB customers by ethnicity/race. The second benchmark was the survey and observation of pedestrians in business districts. Youths stopped in business districts were a benchmark against which to measure the stop data for pedestrians at/near TBs. The survey consisted of five hundred pedestrians in ten business districts at least one mile from TBs. Youths between the ages of twelve to twentyfive comprisod 91 percent, or 455 of 500 pedestrians. The percentage and number of pedestrians in business districts between twelve to twenty-five by ethnicity was:

- White: 60.1 percent (277)

- Chicana/o: 25.3 percent (115)

- Asian American: 11.4 percent (52)

- African American/Other: 2.4 percent (11)

The percentage of individuals in business districts reporting questionings, stop-and-frisks, or both by ethnicity was:

- Chicana/o: 42 percent Questioned, 14 percent Stopped-and-Frisked, 56 pcrcent total.

- White: 6 percent Questioned, 2 percent Stopped-and-Frisked, 8 percent total.

- Asian American: 14 percent Questioned, 9 percent Stopped-and-Frisked, 23 percent total.

- African American/Other: 0 percent for all episodes. 


\section{Ethnic Studies Review Volume 30: 1\&2}

Benchmarking aided in concluding that PQSFE rates in business districts were slightly higher for Chicana/os (51 petcent at/near TBs vs. 56 percent in business districts) and Whites ( 11 percent versus 8 percent) and similar in both areas for Asian Americans (23.3 percent versus 23 percent). PRP of minority youths seemed to not only occur at/near TBs but in business districts.

\section{PSYCHOLOGICAL HARMS}

For many young Chicana/os, PRP and PQSFE were their first encounters with the criminal justice system. They felt victimized, maltreated, and angry as their privacy had been violated (Waldeck 2000: 1284). Fear of police bntality is a psychological harm. Approximately one-third of Chicana/o and Vietnamese American youths indicated fear of being beaten by police when stopped (Author 2004). However, the author did not observe police use of physical force but did observe police micro and macruaggessions at the rate of one per night. Singling out Chicana/o and Vietnamese American youths for PQSFE imposes targeting harms (Waldeck: 1284). Minority youths may feel psychological ham based upon being stopped due to ethnicity (1284). They may respond to these harms with feelings of inferiority, anger, and participation in deviant practices (i.e., joining a gang). PRP intensifies the distrust, anger, and hostility Chicana/o youths have toward police. Minority youths may decline cooperating with police investigations, report crime, or act as willing or unbiased witnesses and jurors (1286).

\section{ELIMINATING POLICE RACIAL PROFILING}

According to Lefebvre, "The right to the city" demands:

....the right of every social group to be involved in all levels of decision making which shape the control and organization of social space. It is also the right not to be excluded from the spaces of the city center and segregated in residential neighborhoods. The right to the center is logically extended by the right to difference: the right to be free from extemally imposod, preestablished classifications of identity (MoCann: 176).

The community, police, and scholars can play an important part in the reduction of PRP.

\section{Community Activism}

- Organize community committees to educate citizens about PRP and how to combat PRP.

- Develop manuals and educate youths on their rights and how to respond to police stops.

- Encourage and assist youths in filing complaints with: 1) local police departments; 2) on the ACLU's "Driver Profiling Complaint Form," that includes pedestrian stops, and; 3) to the Califomia hotline at 1-877-DWB-STOP (1-877-392-7867) (ACLU 2005b). Establish a 
complaint system for youths and a way to present complaints to the city council, mayor, Civilian Police Review Board, and police departments.

- Publicize PRP and organize public protests.

- Create letter-writing campaigns to local, state, and national politicians to end PRP.

- Sign and submit the ACLU's "Urge Congress to Stop Racial Profiling" letter to local U.S. Senators and Representatives (ACLU 2005a).

- Dernand police agencies record demographic data on all pedestrian stops and make that data public.

- Demand that all police officers provide their business card with name, badge number, and time and place of the stop to all stopped pedestrians/motonist.

- Demand that all stops of youths under 18 , and the reasons for those stops, be reported by police to minor's parents.

- Raise money to hire civil rights attomeys to challenge PRP and the Terry ruling in court.

- Bring community organizations (mutual associations, churches, businesses, professional organizations, and schools) together to end PRP.

- Demand a third-party Citizen Review Board of the Police Department.

- Request the federal govemment monitor police departments and force agencies to maintain official records of all pedestrian stops.

- Demand police departments train officers on the negative effects of PRP and have citizens who have experienced PRP participate in training by sharing their experiences.

- Join with other community based organizations and institutions based on ethnic/class/religious groups in combating PRP.

- Use English, Spanish, and Vietnamese (and other) language media to bring PRP to public attention.

- Become involved with the San Jose Bario Defense Committee's "Cop Watch" program that monitors police motoristpedestrian stops and hands out "Know Your Rights" pamphlets to youths (Maiden 2005b).

\section{Police}

- Docurnent and publish demographic data from all stops.

- Require all police officers provide their business card with name, badge number, and time and place of the stop to all stopped pedestrians/motorists.

- Provide officers with training on the negative consequences of PRP to citizens, the city, and the police department.

- Work with the community to understand and eradicate PRP.

- Develop departmental policies against PRP, methods to identify officers using PRP, and disciplining/removal of officers found using PRP. 


\section{Ethnic Studies Review Volume 30: 1\&2}

- Develop community policing with involvement of ethnic groups to meet their needs.

- Require that stops of youths under 18 , and the reasons for those stops, be reported to minor's parents.

\section{Scholars}

- Work with the community and police to eliminate PRP. Act as mediators.

- Choose to do field research with the community on PRP and publish that research.

- Present PRP research to community, police, govt., human right organizations, city council, etc. and publish PRP research.

- Seek funding for PRP research.

- Participate in public forums to end PRP.

- Provide training to third parties in prevention and reduction of PRP.

\section{CONCLUSION}

Police racial profiling in San Jose is also the SJ, or San Jose, Syndrome instead of the TB, Taco Bell, Syndrome as police racially profiled and PQSFE'd minority youths at high rates in business distric and at/near TBs. Minority youths reported police routinely stopping and questioning them about their gang affiliation and the reason for their presence in neighborhoods, and then being searched. Police detained and questioned young Chicana/o pedestrians in TB parking lots. Police detained and questioned Chicano and Vietnamese American youth motorists parked in TB parking lots and business distric with the possible search of their automobiles.

Police detained, questioned, and searched Whites at/near TBs and in business districs at lower rates than Chicana/os and Vietnamese Americans. Due to this targeting Chicana/os felt like inferior citizens. In the words of a sixteen year-old Chicana:

We (Chicana/os) are always treated different than Anglos. We have to be careful where we are, what we are doing, how we are dressed, what part of town we are in, who we are with, and everything else. Anglo kids don't have to be careful about anything because they can do anything and go anywhere they want and no one's going to bother them. They have more rights than us. We are treated like we don't belong here though my family has lived here for hundreds of years. The police just do what the Anglos tell them or else they become Anglos and push us around (Author 2004)!

San Jose TBs and business districts are battlefields for spatial sovereignty. The police, not possessing formal legal tools for monitoring and regulating minority youth, developed informal backstage policies that remind minorities of their lesser place. Police racial profiling highlights the state-sanctioned spatial maintenance role of modem policing and preservation of physical, social, and 
psychological space, place, and race boundaries between "clean" and "polluted" people. The battle for public space, especially access to that space, is a battle for place. Petit apartheid discrimination aims to continue a muted grand apartheid. The nation has not logalized this apartheid but it is enculturated in the mores and customs of police and society. As a nineteen year-old Chicano male stated, "Sometimes it's like they [the police] only want White kids to be at Taco Bell. It's like we are not supposed to be there. I think we are supposed to only eat at Mexican taquerias and the Taco Bells are for Whites. We are supposed to stay away from the places where Anglos go. Might as well have White-only signs at Taco Bell and start puttin' in White drinking fountains! Too bad some of the police are Chicanos" (Author 2003).

Chicana/os, especially males, becarne the primary target of San Jose PRP and Vietnamese American males were targeted to a lesser extent. Racism by law (i.e. de jure segregation) transmuted, via the state and its agents, into subtle racism that functioned under the guise of discretion. There is limited documentation by the police, or others, on PRP decision-making and whether race is a variable in the decision-making process. It is within the backstage, the hidden or unexamined regions of police racially based decision-making that PRP policies formulate. This study evidenced petit apartheid maintained by backstage police decision-making as a daily occurrence for minority youth pedestrians.

This article can have an invaluable impact on San Jose police officer's use of racial profiling and PQSFEs. The San Jose Police Department can either chose to ignore the findings of this study or the department can chose to address the issue. The SJPD can follow the above mentioned guidelines for police in the reduction of PRP and create a community in which minority youth do not fear police and willing cooperate with police in the proper conduct of their law enforcement duties. A true end to PRP and the TB Syndrome in San Jose can only be accomplished with the willingness of the SJPD to address the problem.

Throughout this research the author has attempted to contact San Jose City Council members concerning the SJPD's use of racial profiling. The author's communications have generally been ignored or met with sparse interest by those who represent the citizens of San Jose. The author's hope is that by making people aware of San Jose police officers use of PRP the problem will be brought to public attention so that the SJPD, city council members, scholars, and community members can join together to end PRP and revitalize positive communication links between citizens and police.

I would like to thank Dis. Marcos Pirarro and Louis Holscher of the San Jose State University Mexican American Studies Department and Dr. Norberto Valdez of the Colorado State University Department of Anthropology for their invaluable readings, critique, and suggestions during the research and writing of this article. 
Ethnic Studies Review Volume 30: 1\&2

\section{REFERENCES}

Allen-Bell, Angela A. 1997. "The Birth of the Crime Driving While Black (DWB)." Southern University Law Review 25, Fall: 195-225.

American Civil Liberties Union. 2005a. "Urge Congress to End Racial Profiling." (http:/www.aclu.org/RacialEquality/RacialEquality.cfm?ID=9967\&c=133).

—. 2005b. "Driver Profiling Complaint Form." (https://forms.aclu.org/feedlback/ feedhack.cfim

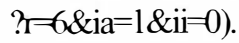

Asian Pacific Islander Legal Outreach. 2003. "Police Killing in San Jose Raises Questions." http://www.geocities.com/apilegaloutreachlUploads/Cautran.htm?20054and\%2OCNN.com/LAW $\%$ OOCENT.

Austin, Regina 1992. "The Black Community,' Its Lawbreakers, and a Politics of Identification.” Southern California Law Review 65: 1769-1817.

Bass, Sandra. 2001. "Out of Place: Petit Apartheid and the Police." Pp. 43-55 in Petit Apartheid in the U.S. Criminal Justice System: The Dark Figure of Racism, edited by Dragan Milovanovic and Katheryn K. Russell. Durham, NC: Carolina Academic Press.

Bay City News. 2004. "Family of Santa Clara Man Killed by Police Demand Open Grand Jury Heaning."

(Bayinsider.com. http://www.ktvu.com/news/4340094/detail.html).

Brooks, Laure W. 1997. "Police Discretionary Behavior. A Study of Style." Pp. 149-166 in Critical Issues in Policing: Contemporary Readings, edited by Roger G. Dunham and Geoffrey P. Alpert. Prospect Heights. IL: Waveland Press.

Brown, Michael K. 1988. Working the Street: Police Discretion and the Dilemmas of Reform. New York: Russell Sage Foundation.

Carter, David L. 1986. “Hispanic Police Officers' Perception of Discrimination.” Police Studies 9, (4) [Winter]: 204-10.

Cheurprakobkit, Sutham 2000. "Police-Citizen Contact and Police Performance: Attitudinal Differences Between Hispanics and Non-Hispanics." Joumal of Criminal Justice 28: 325-36. 


\section{Koehler - Police Racial Profiling}

Christensen, Terry. 1997. "San Jose Becomes the Capital of Silicon Valley." (http://www2.sjsu.eduldeptsPoliSci/faculty/christensenlsj_history.htm).

City of San Jose. 2005a. "Demographic Trend Census Brief: Race and Ethnicity." (http://www.sanjoseca.gov/planning/censuslbriefs/race_ethnicity.html).

City of San Jose. 2005b. "City of San Jose Census Brief: Income and Poverty." (http://www.sanjoseca.gov/planning/census/briefsllncome_Poverty.htm).

Cole, David. 1999. No Equal Justice: Race and Class in the American Criminal Justice System. New York: The New Press.

Cummings, Andre D. P. 1998. "Just Another Gang: 'When the Cops are Crooks Who Can You Trust?"' Howard Law Joumal 41, (2): 383-412.

Davis, Angela C. 1998. "Prosecution and Race: The Power and Privilege of Discretion." Fordham Law Review 67,(3): 13-68.

Dickey, James. (Sept. 19, 1993). “Cops Target Eatery Hours Study: Taco Bells in San Jose are called 'The fast-food choice of gangs."' San Jose Mercury News. 1B.

Dictionary.LaborLawTalk.com. 2005. "San Jose, Califomia." (http://encyclopedialabor lawtalkcom/San_Jose, Califomia).

Fagan, Jeffrey and Garth Davies. 2000. "Street Stops and Broken Windows: Terry, Race, and Disorder in New York City." Fordham Urban Law Joumal 28, December: 457-504.

Ferrell, Jeff. 2001. Tearing Down the Streets: Adventures in Urban Anarchy. New York: Palgrave.

Frazier, John W., Florence M. Margai, and Eugene Tettey-Fio. 2003. Race and Place: Equity Issues in Urban America. Boulder: Westview Press.

Fridell, Lone. 2004. By the Numbers: A Guide for Analyzing Race Data from Vehicle Stops. Washington, D.C.: Police Executive Research Fonum. 


\section{Ethnic Studies Review Volume 30: 1\&2}

Geilhufe, Nancy L. 1979. Chicanos and the Police: A Study of the Politics of Ethnicity in San Jose, California. Monograph - Society for Applied Anthropology, 13. Washington: Society for Applied Anthropology.

Geller, William A. 1988. Deadly Force. Washington, D.C.: U.S. Deprartment of Justice, National Institute of Justice.

Georges-Abeyie, D. 1990a. "Criminal Justice Processing of NonWhite Minorities." Pp. 25-34 in Racism, Empiricism, and Criminal Justice, edited by Brian Maclean and Dragan Milovanovic. Vancouver, British Columbia, Canada: Collective Press.

Goffman, Erving. 1973. The Presentation of Self in Everyday Life. Garden City, NY: Doubleday Anchor Books.

Harris, David A. 1994a “Factors for Reasonable Suspicion: When Black and Poor Means Stopped and Frisked." Indiana Law Journal 69: 659-688.

—. 1994b. "Frisking Every Suspect: The Withering of Temy." U C. Davis Law Review 28, (1): $1-52$.

- 1999a "The Stories, the Statistics, and the Law: Why 'Driving While Black' Matters." MinnesotaLaw Review 84, (2): 265-326.

—. 1999b. "Driving While Black: Racial Profiling on Our Nation's Highways." American Civil Liberties Union June 1999 Special Report. New York, NY: ACLU.

Holmes, Malcolm D. 1998. "Perceptions of Abusive Police Practices in a U.S.-Mexico Border Community." The Social Science Joumal 35, (1): 107-118.

Huang, Wilson S. and Michael S. Vaughn. 1996. "Support and Confidence in Public Attitudes Toward the Police." Pp. 31-45 in Americans View Crime and Justice: A National Public Opinion Sunvy, edited by Timothy J. Flanagan and Dennis R. Longmire. Thousand Oaks, CA: Sage Publications.

Justice for Rudy. 2004. "Justice for Rudy." (http://rudycardenas.net/index.htm).

Larrabee, Jennifer A. 1997. 'DWB (Driving While Black)' and Equal Protection: The Realities of an Unconstitutional Police Practice.” Journal of Law and Policy 6: 291-328. 


\section{Koehler — Police Racial Profiling}

Lind, Allen E. and Tom R. Tyler. 1988. The Social Psychology of Procectural Justice. New York: Harcourt Brace Jovanovich.

Maclin, Tracey. 1998. “Teny V. Ohio's Fourth Amendment Legacy: Black Men and Police Discretion.”' St. John's Law Review 72, (Summer/Fall): 1271-1321.

—. 2000. "Race and the Fourth Amendment." Washington University Law Quarterly 78, (Fall): $675-87$.

Magee, Robin K. 1994. "The Myth of the Good Cop and the Inadequacy of Fouth Amendment Remedies for Black Men: Contrasting Presumptions of Innocence and Guilt." Capital University Law Review 23: 151-219.

Maiden, Peter. 2005a. "Tasers, Beatings, \& Systematic Abuse: An Inside Look at San Jose Police Brutality."

Faultlines. (http://www.indybay.org/news/2005/03/1726575.php).

—. 2005b. "An Evening Spent With Cop Watch." San Francisco Bay Area Independent Media Center. http://www.indybay.org/news/2005/04/1.php.

McCann, Eugene J. 1999. "Race, Protest, and Public Space: Contextualizing Lefebvre in the U.S. City." Antipode 31, (2): 163-84.

Milovanovic, Dragan and Katheryn K. Russell. 2001. Petit Apartheid in the US. Criminal Justice System: The Dark Figure of Racism. Durham, NC: Carolina Academic Press.

Mirandé, Alfredo. 1981. "The Chicano and the Law: An Analysis of Community-Police Conflict in an Urban Bario." Pacific Sociological Review 24: 65-86.

Mirandé, Alfredo. 1987. Gringo.Justice. Notre Dame, IN: University of Notre Dame Press.

Morales, Ammando. 1972. Ando Sangrando (I am Bleeding): A Study of Mexican AmericanPolice Conflict. La Puente, CA: Perspective Publications.

NBC11.com. 2004. "Grand Jury Returns Indictment in Cardenas Shooting." NBC11.com news. (http://www.nbcl 1.com/news/3588049/detail.html). 


\section{Ethnic Studies Review Volume 30: 1\&2}

Ogletree, Jr., Charles J., Mary Prosser, Abbe Smith, and William Talley, Jr. 1995. Beyond the Rodney King Story: An Investigation of Police Conduct in Minority Communities. Boston: Northeastem University Press.

Parenti, Chnistian. 1999. Lockdown America: Police and Prisons in the Age of Crisis. New York: Verso.

Petersilia, Joan. 1983. Racial Disparities in the Criminal Justice System. Santa Monica, CA: Rand Corporation.

PORAC Legal Defense Fund. 2000. "Officer Exonerated in Public Grand Jury Procerdings." Legal Defense Fund News Articles.

(http://www.porac.org/df/articles/august\%201\%201996.html).

Razack, Sherene H. 2002. Race, Space, and the Law: Unmapping a Settler Society. Toronto: Between the Lines.

Reizel, John D., Stephen K. Rice, and Alex R. Piquero. 2004. "Lines and Shadows: Perceptions of Racial Profiling and the Hispanic Experience." Journal of Criminal Justice 32, 6, NovemberDecember. 607-16.

Rice, Stephen K. and Alex R. Piquero. 2005. "Perceptions of Discrimination and justice in New York City." Policing: An Intemational Journal of Police Strategies \& Management, 28, (1): 98117.

Rice, Stephen K, John D. Reizzel, and Alex R. Piquero. 2005. "Shades of Brown: Perceptions of Racial Profiling and the Hispanic Experience." Journal of Ethnicity in Criminal Justice 3, 1/2: 47-70.

Rudovsky, David. 2002. "Breaking the Pattem of Racial Profiling." Trial 38, (August): 28-37.

Russell, Katheryn K. 1998. The Color of Crime: Racial Hoaxes, White Fear, Black Protectionism, Police Harassment, and Other Microaggressions. New York: New York University Press.

—. 1999. "Driving While Black': Corollary Phenomena and Collateral Consequences." Boston College Law Review 40, (May): 717-31.

Salecn, Omar. 1997. "The Age of Unreason: The Impact of Reasonableness, Increased Police Force, and Colorblindness on Temy “Stop and Frisk” Oklahoma Law Review 50, (4): 451-93. 
San Jose Police Department. 2005a. "Vehicle Stop Demographic Study: 2001." (http://www. sjpd.org/_images/Vehicle5tops2001 .pdf).

San Jose Police Department. 2005b. "Frequently Asked Questions." (http://www.sjpd.org/ FAQ.cfm).

Sandler, Norton. 1996. "Jury Lets Killer Cop Off the Hook in Califomia." The Militant. (http://themilitant.com/1 996/6028/6028_31 .html).

Shuford, Reginald T. 1999. "Civil Rights in the Next Millennium: Any Way You Slice It: Why Racial Profiling is Wrong." Saint Louis University Public Law Review 18: 371-80.

Sibley, David. 1995. Geographies of Exclusion: Society and Difference in the West. New York:Routledge.

Smith, Phillip S. 2004. "Raising Awareness of the Consequences of Drug Prohibition." Drug War Chronicle. (http://stopthodnugwar.org/chronicle/326/full.shtml).

Spitzer, Eliot. 1999. "The New York City Police Department's 'Stop and Frisk' Practices: A Report to the People of the State of New York from the Office of the Attomey General." Albany, NY: New York Attomey General's Office.

Stolen Lives Project. 1999. "San Francisco Bay Area/Northem Califomia.” Stolen Lives: Killed by Law Enforcement. (http://stolenlives.org/read/index.php?action= show\&section=area_sanfrancisco_bay_area_northem_califomia.xml\&display SAN+FRANCISCO + +BAY+AREA+\%2F-FNORTHERN+CALIFORNIA\&area=43).

Stuchinsky, Laura. 1996. "Line of Fire: 'Independent' Police Auditor Tries to Build Trust with only the Power of Persuasion." Metro: Silicon Valley's Weekly Newspaper. (http://www.metraactive.com/papers/metro/0 1.25.96/police-9604.html).

Thaman, Stephen C. 2000. "Is America a Systematic Violator of Human Rights in the Administration of Criminal Justice.” Saint Louis University Law Joumal 44, (Summer): 999-1023.

Tyler, Tom R 2002. "A National Survey for Monitoring Police Legitimacy." Justice Research and Policy 4: 71-86. 


\section{Ethnic Studies Review Volume 30: 1\&2}

Tyler, Tom R and Yuen J. Huo. 2002. Trust in the Law: Encouraging Public Cooperation with the Police and Courts. New York: Russell Sage Foundation.

U.S. Census Bureau. 2000a. "City of San Jose: Race Ethnic Group Majority by Census Tract" (httpp://www.sanjoseca.gov/planning/census/maps/Race Majority.pdf).

—. 2000b. "City of San Jose: Poverty Status by Census Tract" (http://www.sanjoseca.gov/ planning/Census/maps/poverty_status.pdf).

—. 2000c. "Sex by Age." (http://factfinder.census.org/servletDTTable?_bm= y\&-geo_id 6000US0668000\&-ds_na...).

Van Maanen, John. 1974. "Working the Street: A Developmental View of Police Behavior.” Pp. 83-130 in The Potential for Reform of Criminal Justice, edited by Herbert Jacob. Beverly Hills, CA: Sage Publications.

Villamuel, Francisco A., Nancy Walker, Pamela Minifee, Omara Rivera-Vázquez, Susan Peterson, and Kristen Perry. 2004. "Dónde está la Justicia: A Call to Action on Behalf of Latino and Latina Youth in the U.S. Justice System." Michigan State University: Institute for Children, Youth, and Families. http://www.buildingblocksfoiyouth.org/atino_pt/full_eng.html.

Waldeck, Sarah E. 2000. "Cops, Community Policing and the Social Norms Approach to Crime Control." Georgia Law Review34, (2): 1253-1310.

Walker, Samuel. 2001. "Searching for the Denominator: Problems with Police Traffic Stop Data and Early Waming System Solution." Justice Research and Policy 3: 63-95.

Walker, Samuel, Cassia Spohn, and Miriam DeLone. 1996. The Color of Justice: Race, Ethnicity, and Crime in America. New York: Wadsworth Publishing Company.

Zapler, Mike. 2003. "S.J. Police Brutality Lawsuit: $\$ 390,000$ for Man Whose Skull was Fracturod." Califormia Lomyers-San Francisco Attorneys-Scarlett Law Group. (http:/www. scarlettlawgroup.com/news).

\section{NOTES}

Taco Bells located at 720 Story Road and 1299 South First. 